\title{
Study on Causes of Respiratory Disease to the Middle East Respiratory Syndrome-negative Subjects
}

\author{
Su-Jeong Hwang ${ }^{*}$, Dong-Ju Park, Hee-Soo Koo, Ho-Cheol Yun, \\ Pyeung-Tae Gu, Mi-Ok Lee and Sung-Hyun Jin \\ Busan Metropolitan City Institute of Health \& Environment, Busan, Korea
}

\begin{abstract}
Middle East respiratory syndrome coronavirus (MERS-CoV) causes severe cases of human respiratory disease. The current outbreak of infection with this virus in South Korea, which began on May 20, 2015, has infected 186 patients and caused 36 deaths within 2 months. In this study, to investigate the viral pathogen causing acute respiratory infections, multiplex/RT-PCR was performed on were obtained from nucleic acid of the Middle East Respiratory Syndrome-negative subjects. Viruses and atypical bacteria were detected in 39 of 337 (11.6\%). Frequent viruses were human rhinovirus $(\mathrm{n}=11,3.3 \%)$, human metapneumovirus $(\mathrm{n}=9,2.7 \%)$, parainfluenza $(\mathrm{n}=9,2.7 \%)$ and adenovirus $(\mathrm{n}=4,1.2 \%)$. Mycoplasma pneumonia (M. pneumonia) was detected in $1.8 \%(\mathrm{n}=6)$. Out of 9 human metapneumovirus (hMPV) positive samples, 6 samples were successfully sequenced using $\mathrm{F}$ gene. And M. pneumoniae was sequencing of a repetitive region of the $\mathrm{P} 1$ gene. Phylogenetic analysis revealed that $\mathrm{hMPV}$ clustered into A2b lineage $(\mathrm{n}=4), \mathrm{B} 2$ lineage $(\mathrm{n}=2)$ and M. pneumoniae clustered into two genotypes: Type $1(n=4)$, Type $2 a(n=2)$.
\end{abstract}

Key Words: Middle East respiratory syndrome coronavirus (MERS-CoV), Human Metapneumovirus (hMPV), Mycoplasma pneumonia (M. pneumonia), Phylogenetic analysis

\section{INTRODUCTION}

중동호흡기증후군(Middle East Respiratory Syndrome, MERS)은 사우디아라비아에서 2012년 첫 환자가 보고된 이후 2016년 10 월까지 세계적으로 1,843 명의 확진자와 705 명의 사망자가 보고되고 있으며 발생환자 대부분 중 동지역과 직·간접적으로 관련이 있는 것으로 나타났다 (1). MERS는 중동호흡기증후군 코로나바이러스(Middle East Respiratory Syndrome Coronavirus, MERS-CoV)에 의하 여 발생한다. MERS-CoV에 감염 시, 중증급성하기도질환 을 유발하여 사망에 이르게 하는데 특히, 기저질환을 가
진 환자의 경우 높은 치사율을 보인다. 동물과 사람, 사람 과 사람 간에 전파되며, 사람과 사람 간 전파는 주로 병원 내에서 일어나는 것으로 알려져 있다 (2).

우리나라에서는 2015년 5월 20일 처음으로 MERS 환자 가 발생하여 같은 해 12 월 23 일 유행종료를 선언한 날까 지 217 일간 총 186 명의 확진자, 36 명의 사망자 및 16,693 명의 격리자가 발생하였다. 주로 병원 내 전파로 감염됨 에 따라 지역사회로의 전파는 없었지만 중동지역을 제외 한 지역에서 가장 많은 감염자가 발생한 것이다.

부산에서는 2015년 6월 3일 첫 의심환자가 발생하였다. 이후 유행이 종료되기 전까지 총 380 건의 의심환자 검체 가 부산광역시 보건환경연구원에 접수되었고 3명의 확진

Received: July 3, 2017/ Revised: September 1, 2017/ Accepted: September 14, 2017

Corresponding author: Su-Jeong Hwang. Busan Metropolitan City Institute of Health \& Environment, 120, Hambakbong-ro 140 beon-gil, Buk-gu, Busan 46616, Korea

Phone: +82-51-309-2815, Fax: +82-51-309-2819, e-mail: kies98@korea.kr

@This is an Open Access article distributed under the terms of the Creative Commons Attribution Non-Commercial License (http://creativecommons.org/license/by-nc/3.0/), 
자가 발생하여 이 중 1 명이 사망하였다. 실험실 진단검사 는 다음의 의심환자일 경우 진행이 된다 1 . 발열과 동반되 는 폐렴 또는 급성호흡기증후군(임상적 또는 방사선학적 진단)이 있으면서 증상이 나타나기 전 14일 이내에 중동 지역을 방문한 자 또는 중동지역을 방문한 후 14일 이내 에 발열과 급성호흡기증상이 나타난 자와 밀접하게 접촉 한 자, 2. 발열과 호흡기증상(기침, 호흡곤란 등)이 있으면 서, 증상이 나타나기 전 14 일 이내에 중동지역 의료기관 에 직원, 환자, 방문자로 있었던 자, 3. 발열 또는 호흡기증 상이 있고, 중동호흡기증후군 확진환자가 증상이 있는 동 안 밀접하게 접촉한 자, 4. 발열과 호흡기증상이 있으면서 14 일 이내에 중동호흡기증후군이 유행한 의료기관에 직 원, 환자, 방문자로 있었던 자.] 기본적으로 발열과 호흡 기증상이 있을 때 MERS-CoV 진단검사가 진행되는 것이 다. 이와 같은 조건으로 인하여 본 원에 의뢰된 MERS 의심환자 대부분 발열과 호흡기증상이 있었고 19 세 이상 의 성인환자였다. 하지만, 결과적으로 MERS 의심체 중 3건만 양성으로 확인되었고 그 외는 모두 MERS 음성으 로 판정이 되었다. 이렇듯 대다수의 의심체에서 MERS$\mathrm{CoV}$ 는 확인되지 않았지만, 성인환자에서 발열과 호흡기 증상 등을 유발하는 다른 병원체의 존재는 충분히 의심해 볼 수 있다.

일반적으로, 성인뿐만 아니라 소아에서의 호흡기질환은 사망률이 높지는 않지만 전염성이 매우 높아 단시간에 폭 발적으로 유행을 한다. 또한 기저질환을 갖고 있거나 미 숙아의 경우는 치명적일 수 있기 때문에 원인병원체의 규 명이나 유행양상 등의 연구는 국내·외에서 활발하게 진 행되었다. 하지만, 기존의 호흡기질환 원인 연구는 주로 소아에만 국한되어 있으며. 성인을 대상으로 하여 호흡기 질환을 일으키는 원인병원체의 유행양상을 분석한 연구는 미비한 실정이다.

이에 본 연구는 부산 내 발생한 MERS 의심환자 중 음 성으로 확인된 환자(만 19세 이상의 성인환자)에서 호흡 기질환을 일으키는 원인병원체를 확인하였다. 그리고 병 원체별 검출빈도 및 양상을 파악하여 그 특성을 분석하 고자 하였다. 또한 확인된 원인병원체 중 의미 있게 검출 된 human metapneumovirus와 호흡기 세균인 Mycoplasma pneumonia에 대해서는 유전자분석을 진행하였다.

\section{MATERIALS AND METHODS}

\section{연구대상}

'중동호흡기증후군(MERS) 관리지침'에 의거하여 2015년 부산 관내에서 의뢰된 중동호흡기증후군 의심검체(객담) 는 380 건으로, 이 중 음성으로 확인된 검체는 377건이다. 377 건 중 만 19 세 이상의 성인환자 검체는 337 건 이었고, 이들의 MERS-CoV 확인 검사를 하고 남은 핵산을 대상으 로 호흡기병원체를 검사하였다. 그리고 검사 의뢰 시 확 보된 검체 의뢰서(익명화 과정 거침)에서 성별, 연령, 임상 증상 등에 대한 자료를 추출하였다.

\section{병원체 검출}

호흡기바이러스는 Multiplex real-time PCR/RT-PCR kit (Kogenebioteck, Korea)를 이용하여 adenovirus, human bocavirus, parainfluenza virus 1,2,3, hunan coronavirus 229E, CC43, NL63, respiratory syncytial virus A, B, human metapneumovirus, human rhinovirus, influenza virus $\mathrm{A} / \mathrm{H} 1 \mathrm{~N} 1 \mathrm{pdm} 09, \mathrm{~A} /$ $\mathrm{H} 3 \mathrm{~N} 2, \mathrm{~A} / \mathrm{H} 5 \mathrm{~N} 1, \mathrm{~B}$ 의 8 종 16 아형을 대상으로 검사하였다. 호흡기 세균은 Mycoplasma pneumonia, Bordetella pertussis, Chlamydophila pneumoniae 이 동시에 검출 가능한 Respiratory Bacteria II real-time PCR kit (Kogenebioteck)를 이용하 였다. 잔여 핵산을 진단키트에 첨가한 후, 7500 Fast RealTime PCR System (Applied Biosystems, Foster City, CA, USA) 를 사용하여 해당 매뉴얼에 따라 분석하였다.

Human metapneumovirus (hMPV)의 염기서열 분석

$\mathrm{hMPV}$ 의 염기서열 분석은 DiaStar 2X OneStep RT-PCR Pre-Mix Kit (Solgent, Korea)를 사용하여 semi-nested PCR 방법을 수행하였다. 1차 PCR Primer로 3637F, 4192R1, 4192R2를 semi-nested PCR은 3637F, 4164R을 이용하여 다음의 조건으로 실시하였다 (3). 1 차 $\mathrm{PCR}$ 은 $45^{\circ} \mathrm{C} 30$ 분, $94^{\circ} \mathrm{C} 5$ 분을 1 회 진행 후, $94^{\circ} \mathrm{C} 30$ 초, $60^{\circ} \mathrm{C} 30$ 초, $72^{\circ} \mathrm{C} 45$ 초 40 회, $72^{\circ} \mathrm{C} 10$ 분 반응시켰다. 반응 후, $\mathrm{PCR}$ 증폭산물은 $1 \%$ agarose gel (Invitrogen, USA)에서 전기영동 하였고 그 결과는 Image analyzer (Geldoc XR image system, BioRad, Hercules, CA, USA)로 $555 \mathrm{bp}$ 의 PCR band를 확인하였다. Semi-nested $\mathrm{PCR}$ 은 전기영동 결과 음성으로 확인된 건 에 대해서 실시하였다. 1 차 $\mathrm{PCR}$ 산물을 주형으로 하여 annealing 온도만 $66^{\circ} \mathrm{C}$ 로 변경하여 1 차 $\mathrm{PCR}$ 과 같은 조건 
Table 1. Primers used in this study

\begin{tabular}{|c|c|c|c|c|c|}
\hline Agent & Primer purpose & Primer & Sequence $\left(5^{\prime}-3^{\prime}\right)$ & $\begin{array}{l}\text { Target } \\
\text { genes }\end{array}$ & $\begin{array}{l}\text { Size (bp) } \\
\text { of product }\end{array}$ \\
\hline \multirow{4}{*}{ hMPV } & \multirow{4}{*}{ Semi-Nested PCR } & $3637 \mathrm{~F}$ & GTY AGC TTC AGT CAA TTC AAC AGAAG & \multirow{4}{*}{$\mathrm{F}$} & \multirow{2}{*}{555} \\
\hline & & 4192R1 & CAG TGA AAC CAT ACT GAT RGG ATG & & \\
\hline & & 4192R2 & TAG TGC AAC CAT ACT GAT RGG GTG & & \multirow{2}{*}{527} \\
\hline & & 4164R & CCT GTG CTG ACT TTG CAT CAT GGG & & \\
\hline \multirow{4}{*}{$\mathrm{Mp}$} & \multirow{2}{*}{ First amplification } & Mp5f & TTG ACA AGA CCG TCC AAT CC & & \multirow{2}{*}{2,465} \\
\hline & & Mp16r & TTG GTT GGG TAT CTT GAT CAG G & & \\
\hline & \multirow{2}{*}{ Nested PCR } & Mp11f & CCT CGT TGT CAG TGG CAC C & 11 & \multirow{2}{*}{533} \\
\hline & & Mp14r & GCT GGG TGG AAT GGT CTG TAC & & \\
\hline
\end{tabular}

으로 실시 후, $527 \mathrm{bp}$ 의 PCR band를 확인하였다(Table 1).

PCR 증폭산물에 대한 염기서열 분석(Macrogen, Korea) 을 의뢰하여 확인된 염기서열은 Lasergene sequence analysis software package (DNAStar, Madison, WI, USA) 프로그램을 이용하여 분석하였다. NCBI GenBank database에 등록된 기 존 표준주 염기서열과 비교·분석하였고 Clustal X를 이용 하여 multiple alignment를 수행하였다. 계통분석은 MEGA 4 를 사용하여 Maximum composite likelihood의 근린결합분 석(neighbor-joining: NJ)방법으로 시행하였다. 계통수 분지 에 대한 지지도 측정을 위하여 부스트랩(bootstrap)값을 1,000 회 반복하였고 branch node는 부스트랩(bootstrap) $70 \%$ 이상의 값만 표현하였다.

\section{Mycoplasma pneumonia (M. pneumonia)의 유전형 분석}

M. pneumonia의 유전형을 확인하기 위하여 Maxim PCR PreMix (INtRON Biotechnology, Korea)를 사용하여 nested $\mathrm{PCR}$ 을 수행하였다. 사용한 Primer는 Table 1과 같다. 1차 $\mathrm{PCR}$ 조건은 $94^{\circ} \mathrm{C} 3$ 분 1 회 진행 후, $94^{\circ} \mathrm{C} 60$ 초, $58^{\circ} \mathrm{C} 60$ 초, $72^{\circ} \mathrm{C} 3$ 분 35 회, $72^{\circ} \mathrm{C} 10$ 분 반응시켰으며, nested PCR에서 는 1 차 PCR 산물을 주형으로 하여 반응 cycle 수만 30 회 로 변경한 후, $533 \mathrm{bp}$ size의 PCR band를 확인하였다 (4).

\section{연구윤리 심의(Ethical statement)}

본 연구는 보건복지부 지정 공용기관생명윤리위원회의 승인을 받았다(승인번호 P01-201601-33-002).

\section{RESULTS AND DISCUSSION}

병원체 검출 현황

만 19 세 이상의 성인환자 검체의 핵산 337 건을 대상으 로 호흡기병원체 감염여부를 확인한 결과 총 39 명(11.6\%) 에서 병원체를 확인할 수 있었다. 이 중 호흡기바이러스 는 33 건 분리되어 $9.8 \%$ 의 양성률을 보였고, 호흡기 세균 은 $1.8 \%$ (6/337)이었다. 바이러스의 경우 human rhinovirus (hRV)가 11건(3.2\%), human metapneumovirus (hMPV), parainfluenzavirus (PIV) 각각 9건(2.7\%) 그리고 adenovirus $(\mathrm{ADV})$ 가 4 건 $(1.2 \%)$ 검출되었다. 세균은 Mycoplasma pneumonia (M. pneumonia)만이 6건(1.8\%) 검출된 것으로 나타 났다. 전체적으로 검출 대상이 적어 유행양상에 대하여 분석할 만큼 충분 자료가 부족하고 소아나 영유아가 아 닌 성인환자를 대상으로 하여 기존에 보고된 결과와는 다 를 수도 있다. 본 연구의 검출 양상 등을 살펴본 바는 다 음과 같다(Table 2).

$\mathrm{hRV}$ 의 경우 영 유아나 면역력 저하 환자 및 고령환자 에서 심각한 하기도감염증을 일으키는 바이러스로 알려져 있으며 $(5,6)$ 국내에서 실시되는 호흡기질환 하기도감염 증 감시망인 '급성기관지염에 대한 원인병원체 분석' 운영 결과에서도 $\mathrm{hRV}$ 로 인한 감염이 감염이 가장 높다고 보 고하고 있다 (7). 하기도 검체의 핵산으로 진행한 본 연구 에서도 가장 높은 검출률을 보였다. 그리고, 호흡기질환 상기도감염증 감시망인 '인플루엔자 및 호흡기바이러스 실험실감시(Korea Influenza and Respiratory Surveillance 
Table 2. Detection status of respiratory pathogens

\begin{tabular}{ccccccccccccc}
\hline \hline & Total & ADV & hBoV & PIV & RSV & IFV & hCoV & hRV & hMPV & Mp & Cp & Bp \\
\hline No. of detection & 39 & 4 & 0 & 9 & 0 & 0 & 0 & 11 & 9 & 6 & 0 & 0 \\
$\%$ & 11.6 & 1.2 & 0.0 & 2.7 & 0.0 & 0.0 & 0.0 & 3.2 & 2.7 & 1.8 & 0 & 0 \\
\hline
\end{tabular}

$\mathrm{ADV}$ : adenovirus, $\mathrm{hBoV}$ : human bocavirus, PIV:parainfluenza virus, RSV: respiratory syncytial virus, IFV: influenza virus, hCoV: human coronavirus, hRV: human rhinovirus, hMPV: human Metapneumovirus, Mp: Mycoplasma pneumonia, Cp: Chlamydophila pneumoniae, Bp: Bordetella pertussis

System, KINRESS)'사업에서도 연중 지속적으로 검출되는 것으로 확인되어 (8), 상- 하기도에서 호흡기감염증을 일으 키는 주된 원인으로 나타났다.

9건이 검출된 $\mathrm{hMPV}$ 는 영·유아에서 감기, 세기관지염, 폐렴, 크롭 및 반응성 기도질환 같은 하기도 질환과 연관 되며 천식의 발생, 반복적인 천명과 같은 중증질환의 위 험과 관련이 있다고 보고되고 있다 $(9,10)$. 북미에서는 주로 겨울철에 유행하며 1,2 월에 절정으로 이루는 것으 로 알려져 있고 (11) 네덜란드의 경우 12 월, 캐나다는 4월 그리고 홍콩은 봄과 초여름에 절정을 이루는 것으로 나타 났다 $(12,13)$. 그리고 국내에서 수행된 성인의 급성호흡 기 바이러스 감염에 대한 연구를 살펴보면, 일반적으로 hMPV가 3 5월 사이에 주로 유행되었으나 2015년에는 유행이 1 개월 일찍 시작되고 좀 더 오래 지속되었다고 한 다 (14). MERS 의심검체의 주 의뢰기간이 6 7월인 본 연 구에서도 $\mathrm{hMPV}$ 의 검출률이 상대적으로 높은 것으로 나 타나 기존 연구와 유사한 결과를 보였다.

$\mathrm{PIV}$ 는 $\mathrm{hRV}$ 에 이어 $\mathrm{hMPV}$ 와 함께 두 번째로 빈도가 높 게 나타났다. 일반적으로 경미한 증상에서부터 감기, 크롭, 기관지염까지 다양한 감염을 일으키는 바이러스이다. 보 통 온대지방에서는 1,2 형이 여름과 가을에 유행하며 3형 은 산발적으로 유행하는 것으로 알려져 있다 (15). 우리나 라도 4월 초 발생하기 시작하여 9월경에 감소하는 하절기 유행하는 바이러스로 확인되며 (8) 비슷한 시기에 행해진 본 연구에서도 높은 검출률을 보였다.

호흡기 세균은 M. pneumonia만이 검출되었다. 이로 인한 호흡기질환은 비말감염을 통하여 발병이 되며 주로 폐렴 이나 기관지염을 일으키고 또한 인두염, 크룹, 모세기관지 염 등을 일으키는 것으로 보고되고 있다 (16). 또한 3 4년 을 주기로 발생이 증가하고, 겨울철에 호발한다 (17).

\section{연령군별 성별 병원체 검출 현황}

연령군별 병원체 검출률을 확인한 결과 50 59세에서 $25.0 \%$ (10/40)으로 가장 높게 나왔고 40 49세 14.3\% (6/42), 30 39세 $14.0 \%$ (8/57), 60 세 이상 9.2\% (13/141), 18 29세 $3.5 \%(2 / 57)$ 순이었다. 그리고 성별에 따른 병원체 검출 차이는 없었다(Fig. 1, Table 3).

50 59세군에서는 PIV가 $12.5 \%$ 로 분포도가 높았고 30 39세군에서는 $\mathrm{hRV}$ 가 $10.5 \%$ 로 많이 검출된 것으로 확인 되었다. 60 세 이상의 연령군에는 $\mathrm{hMPV}$ 의 검출률이 가장 높은 것으로 나타났다. 기존에 보고된 연구를 살펴보면, 성인군의 $\mathrm{hMPV}$ 감염비율은 전체적으로 소아에서 관찰되 는 수준보다는 낮지만 성인군에서의 감염은 더 flu-like하 고 천식, 심부전 및 만성폐쇄성 폐질환의 급성악화에 관 여한다고 한다 (18). 그리고 $\mathrm{hMPV}$ 로 인한 호흡기질환의 주요 위험인자는 고령일수록, 심폐질환이 기저질환으로 있을 때 더 높은 것으로 알려져 있다 (19). 그러므로 면역 력 저하 환자 및 고령환자에서의 호흡기감염 위험에 있 어서 보건학적으로 의미가 있는 병원체로 사료된다. $M$. pneumonia는 학동기 아동이나 영·유아가 주 감염층인 것 으로 알려져 있다 (17). 본 연구는 만 19세 이상을 대상으 로 하였기 때문에 비교가 불가하며, 6 건 모두 40세 이상에 서 검출된 것으로 확인되었다.

\section{$\mathrm{hMPV}$ 의 계통분석}

hMPV는 2001년 네덜란드의 van den Hoogen에 의해 최초 보고되었다. 소아 하기도 감염 환아의 검체에서 분리 된 바이러스 중 기존 바이러스 분류에는 속하지 않았던 28 주의 바이러스를 분석하여 새로운 RNA 바이러스를 확 인한 것이다 (12). 이후 전 세계에서 발견되었고 가벼운 상기도 감염에서 심한 폐렴까지 다양한 임상경과를 보이 며, 임상양상이 RSV 감염과 비슷하여 임상적으로는 구 


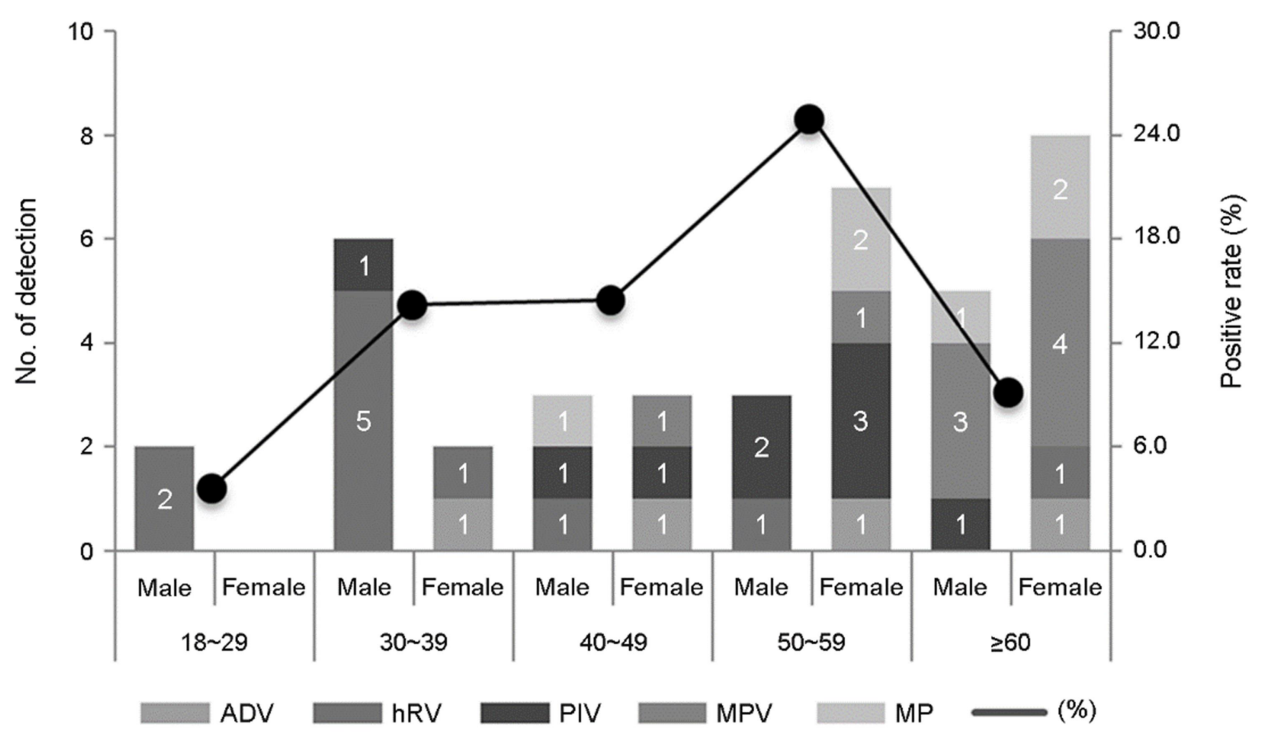

Patient age, $y$

Figure 1. Age and sex distribution of respiratory pathogens. Percentage of positive samples for each age group: 19 29 y, 3.5\%; 30 39 y, $14.0 \%$; 40 49 y, $14.3 \%, 50 \sim 59 \mathrm{y}, 25.0 \% ; \geq 60 \mathrm{y}, 9.2 \%$.

Table 3. Respiratory pathogens finding according to patient's age groups

\begin{tabular}{lcccccc}
\hline \hline Respiratory pathogens & $\begin{array}{c}\text { No. }(\%) \text { of } \\
\text { detection }\end{array}$ & $\begin{array}{c}18 \sim 29 \\
(\mathrm{n}=57)\end{array}$ & $\begin{array}{c}30 \sim 39 \\
(\mathrm{n}=57)\end{array}$ & $\begin{array}{c}40 \sim 49 \\
(\mathrm{n}=42)\end{array}$ & $\begin{array}{c}50 \sim 59 \\
(\mathrm{n}=40)\end{array}$ & $\begin{array}{c}\geq 60 \\
(\mathrm{n}=141)\end{array}$ \\
\hline Bacteria & & & & & \\
Mycoplasma pneumonia & $6(1.8)$ & 0 & 0 & $1(2.4)$ & $2(5.0)$ & $3(2.1)$ \\
Chlamydophila pneumoniae & $0(0.0)$ & 0 & 0 & 0 & 0 & 0 \\
Bordetella pertussis & $0(0.0)$ & 0 & 0 & 0 & 0 & 0 \\
Virus & & & & $1(\mathrm{n}, \%)$ \\
Adenovirus & $4(1.2)$ & 0 & $1(1.8)$ & $1(2.4)$ & $1(2.5)$ & $1(0.7)$ \\
Human bocavirus & $0(0.0)$ & 0 & 0 & 0 & 0 & 0 \\
Parainfluenzavirus & $9(2.7)$ & 0 & $1(1.8)$ & $2(4.8)$ & $5(12.5)$ & $1(0.7)$ \\
Human coronavirus & $0(0.0)$ & 0 & 0 & 0 & 0 & 0 \\
Respiratory syncytial virus & $0(0.0)$ & 0 & 0 & 0 & 0 & 0 \\
Metapneumovirus & $9(2.7)$ & 0 & 0 & $1(2.4)$ & $1(2.5)$ & $7(5.0)$ \\
Rhinovirus & $11(3.2)$ & $2(3.5)$ & $6(10.5)$ & $1(2.4)$ & $1(2.8)$ & $1(0.7)$ \\
Influenza virus & $0(0.0)$ & 0 & 0 & 0 & 0 & 0
\end{tabular}

분하기는 힘들다고 알려져 있다 (10). 계통발생학적으로 Paramyxoviridae과의 Pneumovirinae아과의 Metapneumovirus
속에 속하며 외피가 있는 single negative stranded RNA 바 이러스이고 유전적 검사상 avian pneumovirus (APV)와 가 
장 유사하다. hMPV의 유전자는 3'-N-P-M-F-M2-SH-G-L-5' 로 구성되어 있다. 이 중 Protein $(\mathrm{G})$ 과 fusion protein $(\mathrm{F})$ 의 염기서열 분석에 기초하여 2 개의 주요 유전형인 group A 와 $\mathrm{B}$ 로 나뉘고, 각각의 유전형은 다시 2개의 subgroup으 로 나뉘어 $\mathrm{A} 1, \mathrm{~A} 2, \mathrm{~B} 1$ 및 $\mathrm{B} 2$ 이 존재한다. 또한 subgroup $\mathrm{A} 2$ 은 F gene과 nucleocapsid $(\mathrm{N})$ gene의 염기서열 특성에 따라 $\mathrm{A} 2 \mathrm{a}$ 와 $\mathrm{A} 2 \mathrm{~b}$ 으로 분류된다 $(3,20,21)$. 이후 $\mathrm{A} 2 \mathrm{~b}$ 는 $\mathrm{A} 2 \mathrm{~b} 1$ 와 $\mathrm{A} 2 \mathrm{~b} 2$ 로 $\mathrm{B} 2$ 는 $\mathrm{B} 2 \mathrm{a}$ 와 $\mathrm{B} 2 \mathrm{~b}$ 로 나뉜다는 연구가 보 고되기도 하였다 (21).

하기도 검체의 핵산을 대상으로 호흡기병원체 실험을 진행한 결과 $\mathrm{hMPV}$ 의 검출률이 $\mathrm{hRV}$ 에 이어 두 번째로 높게 나온 것을 확인할 수 있었다. 조사기간이 6월부터
11 월까지였기 때문에 동절기바이러스로 알려진 IFV나 $\mathrm{RSV}$ 를 제외하고 보더라도 호흡기감염증의 주원인 병원체 이며 연중 검출되는 것으로 알려진 $\mathrm{ADV}$ 보다도 검출률 이 높게 나온 것이다. $\mathrm{hMPV}$ 양성 9 건 중 6건만이 F gene 이 증폭되었다. 증폭된 6건에 대해서 염기서열 분석 후, BLAST 프로그램으로 상동성이 가장 높은 유전형을 확 인하였다. 그 결과 모두 기존 분리주와 $98 \%$ 이상의 상동 성을 보였고 $\mathrm{A} 2 \mathrm{~b}$ 4건, B2 2건으로 나타났다. A2b는 모두 캐나다에서 분리된 H0910-161-A (GenBank accession no-KF192757)형과 B2는 인도에서 분리된 HMPV/PUNE/NIV11133/92/11 (GenBank accession no.KF731511)과 98\%의 상 동성을 보였다(Fig. 2).

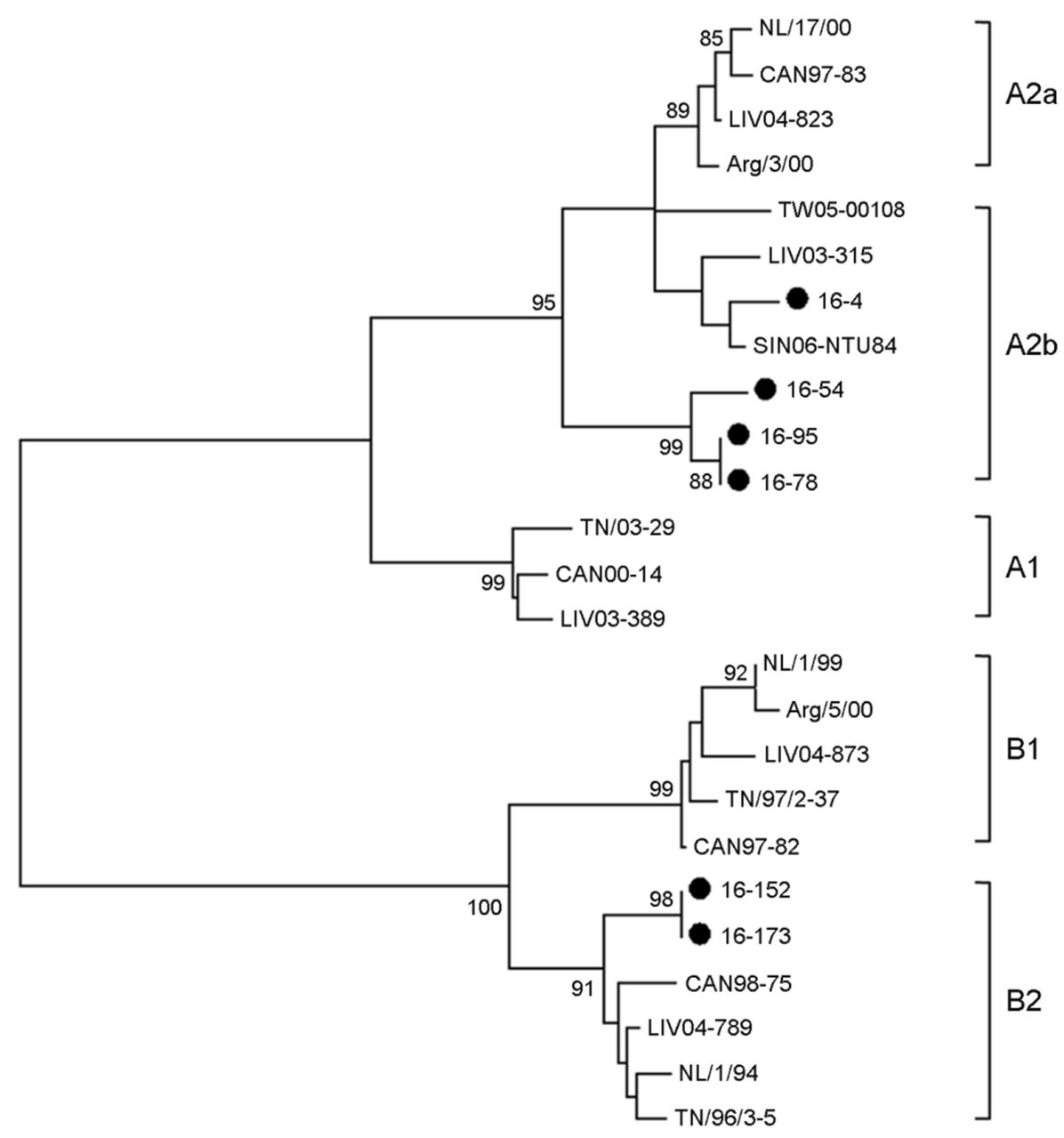

Figure 2. Phylogenetic analysis for HMPV based on of the F protein. The nucleotide sequences were aligned using Clustal W. Trees using the neighbor-joining method with Mega 4 . The scale bars show the proportions of nucleotide substitutions, and the numbers at the branches are bootstrap values determined for 1,000 iterations. Only bootstrap values with $\geq 70 \%$ significance are shown. 
국내에서 실시된 연구들을 살펴보면 5개의 유전형 중 에서 $\mathrm{A} 2 \mathrm{a}$ 와 $\mathrm{A} 2 \mathrm{~b}$ 가 주로 검출되는 것으로 확인되었고 조 사기간 동안 $\mathrm{A} 1$ 은 단 한 건만이 검출되었다 $(13,22,23)$. 본 연구에서는 group $\mathrm{A}$ 중 $\mathrm{A} 2 \mathrm{~b}$ 만이 검출되었는데 연구대 상 연령층이 다르고 MERS가 유행한 기간만 파악하였기 때문에 이와 같은 결과를 보인 것으로 사료된다. 본 연구 에서는 유전형과 유의한 증상과의 관계는 다루지는 않았 지만 $\mathrm{A} 2 \mathrm{a}$ 가 다른 아형에 비해 재채기 증상과 유의한 결 과를 보이는 것으로 보고되고 있다 (22). hMPV의 검출건 수가 적어 이와 같은 관계 등을 파악하는 데에는 한계가 있었다.

\section{M. pneumonia의 유전형 분석}

마이코플라즈마(Mycoplasma)속 균은 세포벽이 없고 크기가 매우 작은 세균이다. 1898년 소에서 우 폐역균 (pleuropneum-onia-like organism, PPLO)을 처음 확인한 후 현재까지 100 여 종 이상의 균 종을 분리하였다 (24). 1937년 사람에게서 마이코플라즈마가 처음 확인되었으며 1963년 이 균에 대한 생물학적 특성이 밝혀지면서 M. pneumonia 로 명명하게 되었다 (16). M. pneumonia는 macrolide계, tertracycline계, fluoroquinoline계 항생제에 대해 감수성이 있는 것으로 알려져 있으나 최근에 일본과 중국에서 macrolide 항생제에 대한 내성균주의 출현과 확산이 보고되고 있다 $(25,26)$.

M. pneumonia의 유전형 분석은 호흡기 내 상피세포에 부착하는 기능을 가진 P1 protein의 유전자를 이용하였다. $\mathrm{P} 1$ gene은 반복인자인 RepMP2/3를 포함하는데 이 부위의 DNA 염기서열 차이에 의해 type 1 과 type 2 형으로 분류되 며, 다시 type 2 형은 $2 \mathrm{a}, 2 \mathrm{~b}$ 로 나뉜다. 이후, $\mathrm{DNA}$ 절편분 석법인 multiple-locus variable-number tandem-repeat analysis (MLVA)을 이용하여 26개(A-Z)의 type으로 분류한 연구가 보고되었다 (27).

M. pneumonia 양성으로 확인된 검체는 총 6건이었다. 6건에 대하여 P1 genotype 분석을 실시한 결과 Type 1형 4건, Type 2a형이 2건으로 나타났다. Type 1형은 모두 기 존에 보고된 Mycoplasma pneumoniae strain S355 (GenBank accession no. CP013829)형과 99\%의 상동성을 보였다. 이 는 중국에서 분리된 것으로 Macrolide계 항생제에 내성이 있는 균주이다. Type $2 \mathrm{a}$ 형은 일본에서 분리된 Mycoplasma pneumoniae 309 DNA (GenBank accession no. AP012303)과 $99 \%$ 의 상동성을 보였다. 상기도감염증에서 M. pneumonia
감염증이 유행한다면 Type 1의 발생빈도가 높고 하기도 감염증에서 유행한다면 Type 2의 빈도가 높다는 보고도 있으나 (17) 하기도 검체로 실시한 본 연구에서는 Type 1 이 더 많이 검출된 것으로 확인되었다.

이 연구를 통하여 MERS 발생시기 중 만 19세 이상의 성인환자에서 호흡기질환을 일으키는 원인병원체를 확인 하였다. 이 중 병원체가 확인된 건은 39 건에 불과하였다. 원인규명률이 낮은 이유로, 첫 번째로는 MERS 의심환자 검사의뢰 시 발열과 호흡기증상이 있을 때 의뢰되는 것이 기본이기는 하나 환자 및 접촉자의 격리를 해제하기 위하 여 의심환자로 의뢰한 후 48 시간이 지난 뒤에 관련 증상 이 없어도 격리 해제를 위하여 본 원에 재 의뢰되기도 하 였다. 의뢰된 검체의 구성을 살펴보면, 337 건 중에서 신규 환자 검체가 185 (54.9\%)건이었으며 격리 해제를 위하여 재 의뢰된 검체가 $152(45.1 \%)$ 건이었다. 재 의뢰된 검체의 비율이 비교적 높은 것이 병원체 확인율을 낮춘 원인으로 보인다. 그렇지만 신규환자 검체의 검출률은 $14.1 \%$ (26/ $185)$ 이고 재 의뢰 검체의 검출률 $8.6 \%(13 / 152)$ 으로 두 개 의 환자군의 검출률 모두 $80 \%$ 이상의 원인불명률을 보인 것으로 나타났다. 그리고 두 번째 이유로는 예방백신과 치 료제가 확립되지 않은 상황에서 MERS가 확산되었기 때 문에 불확실성에 기인하는 사회적인 불안증상과 두려움이 발생했을 것이다. 확진환자 또는 의심환자와 유증상기에 접촉한 밀접접촉자나 확진환자와 동일한 시간 또는 공간 에서 활동한 일상접촉자들은 직·간접적으로 접촉을 하였 다. 그렇기 때문에 자신도 감염될 지 모른다는 심리적인 스트레스가 상승했을 것임은 분명하며 이로 인하여 MERS 에 감염이 되지 않았음에도 불구하고 $\mathrm{MERS}$ 를 의심할 만 한 유사증상들을 발현시킨 것으로 사료된다.

호흡기감염증을 유발하는 원인에는 바이러스와 마이코 플라즈마 그리고 세균 등이 알려져 있다. 바이러스로 인 하여 발생한 호흡기감염증은 대부분 임상증상에 따른 대 증 치료만으로도 호전이 되지만 초기에는 원인을 모르기 때문에 불필요한 항생제가 처방되는 경우가 많다 (8). 또 한 마이코플라즈마의 경우 초기감염증상이 바이러스 폐 렴과 유사하여 구별이 어려워 적절한 치료가 이루어지지 않는다면 중증으로 진행될 가능성이 있다 (17). 따라서 지 역사회에서 유행하는 호흡기감염증의 원인병원체 규명은 적절한 진료나 치료에 긍정적인 효과를 줄 수 있다.

본 연구는 추출된 잔여 핵산으로 연구가 진행되어 검사 대상 선정의 한계가 분명히 존재하며, 항생제내성 검사 등 
의 추가 연구가 불가하여 이로 인한 제약도 있었다. 그리 고 성인환자가 대상이었기 때문에 주로 소아환자를 대상 으로 한 기존의 연구와는 차이가 있을 것으로 사료된다. 또한 검출된 병원체의 수가 전체적으로 적어 기존 연구와 의 비교에도 한계가 있었다. 그러나 성인환자를 대상으로 호흡기바이러스 및 세균을 확인하여 그 양상을 확인하였 다는 것에 의의가 있다. 향후 더 많은 지역에서 성인층을 대상으로 호흡기질환을 일으키는 원인병원체 연구가 진행 이 된다면 연구자료로 활용될 수 있을 것이다.

\section{RERETENCES}

1) World Health Organization (WHO). Middle East respiratory syndrome coronavirus (MERS-CoV) global summary and risk assessment. 2016. Available at http://who.int/ emergencies/mers-cov/mers-summary-2016.pdf.

2) Zumla A, Hui DS, Perlman S. Middle East respiratory syndrome. Lancet 2015;386:995-1007.

3) Reiche J, Jacobsen S, Neubauer K, Hafemann S, Nitsche A, Milde J, et al. Human metapneumovirus: insights from a ten-year molecular and epidemiological analysis in Germany. PLoS One 2014;9:e88342.

4) Dumke R, Lück PC, Noppen C, Schaefer C, von Baum H, Marre $\mathrm{R}$, et al. Culture-independent molecular subtyping of Mycoplasma pneumoniae in clinical samples. J Clin Microbiol 2006;44:2567-70.

5) Mackay IM. Human rhinoviruses: the cold wars resume. J Clin Virol 2008;42:297-320.

6) Hayden FG. Rhinovirus and the lower respiratory tract. Rev Med Virol 2004;14:17-31.

7) Korea Centers for Disease Control and Prevention (KCDC). Analysis of pathogen in acute respiratory infections. Public Health Weekly Report 2014;4:65-72.

8 ) KCDC. The prevalence of the respiratory viruses in the patients with acute respiratory infections 2014. Public Health Weekly Report 2016;9:26-36.

9) Park JS. Acute viral lower respiratory tract infections in children. Korean J Pediatr 2009;52:269-76.

10) Kang SY, Hong CR, Kang HM, Cho EY, Lee HJ, Choi EH, et al. Clinical and epidemiological characteristics of human metapneumovirus infections in comparison with respiratory syncytial virus A and B. Korean J Pediatr Infect Dis 2013; 20:168-77.
11) Williams JV, Harris PA, Tollefson SJ, Halburnt-Rush LL, Pingsterhaus JM, Edwards KM, et al. Human metapneumovirus and lower respiratory tract disease in otherwise healthy infants and children. N Engl J Med 2004;350:443-50.

12) van den Hoogen BG, de Jong JC, Groen J, Kuiken T, de Groot R, Fouchier RA, et al. A newly discovered human pneumovirus isolated from young children with respiratory tract disease. Nat Med 2001;7:719-24.

13) Chung JY, Han TH, Kim BE, Kim CK, Kim SW, Hwang ES. Human metapneumovirus infection in hospitalized children with acute respiratory disease in Korea. J Korean Med Sci 2006;21:838-42.

14) Yang SJ. Etiology of respiratory virus of acute respiratory infection in adult population at a single tertiary care center. Masters Thesis, Gachon University, School of Medicine, 2017.

15) Collins PL, Chanock RM, McIntosh K. Parainfluenza viruses. In: Fields BN, editors. Virology. Philadelphia: Lippincott-Raven;1996. p.1205-41.

16) Kim WK, Kim KE. Mycoplasma and chlamydia infection in Korea. Kor J Pediatr 2009;52:277-82.

17) KCDC. Analysis of genotype distribution and detection rate of Mycoplasma pneumoniae according to respiratory disease type. Public Health Weekly Report 2014;9:177-81.

18) Falsey AR, Walsh EE. Viral pneumonia in older adults Clin Infect Dis 2006;42:518-24.

19) Kahn JS. Epidemiology of human metapneumovirus. Clin Microbiol Rev 2006;19:546-57.

20) Huck B, Scharf G, Neumann-Haefelin D, Puppe W, Weigl J, Falcone V. Novel human metapneumovirus sublineage. Emerg Infect Dis 2006;12:147-50.

21) Neemuchwala A, Duvvuri VR, Marchand-Austin A, Li A, Gubbay JB. Human metapneumovirus prevalence and molecular epidemiology in respiratory outbreaks in Ontario, Canada. J Med Virol 2015;87:269-74.

22) Kim HR, Cho AR, Lee MK, Yun SW, Kim TH. Genotype variability and clinical features of human metapneumovirus isolated from Korean children, 2007 to 2010. J Mol Diagn 2012;14:61-4.

23) Chung JY, Han TH, Kim SW, Hwang ES. Genotype variability of human metapneumovirus, South Korea. J Med Virol 2008;80:902-5.

24) Waites KB, Talkington DF. Mycoplasm pneumoniae and its role as a human pathogen. Clin Microbiol Rev 2004;17: 
697-728.

25) Matsuoka M, Narita M, Okazaki N, Ohya H, Yamazaki T, Ouchi $\mathrm{K}$, et al. Characterization and molecular analysis of macrolide resistance Mycoplasma pneumoniae clinical isolates obtained in Japan. Antimicrob Agents Chemother 2004;48:4624-30.

26) Xin D, Mi Z, Han X, Qin L, Li J, Wei T, et al. Molecular mechanisms of macrolide resistance in clinical isolates of
Mycoplasma pneumoniae from China. Antimicrob Agents Chemother 2009;53:2158-9.

27) Dégrange $S$, Cazanave $C$, Charron A, Renaudin H, Bébéar C, Bébéar CM. Development of multiple-locus variablenumber tandem-repeat analysis for molecular typing of Mycoplasma pneumoniae. J Clin Microbiol 2009;47:914 -23 . 